\title{
Mechanism of fat malabsorption in rats infected with Nippostrongylus brasiliensis
}

\author{
N. D. Gallagher, M. R. Playoust, AND L. E. A. SYMONS \\ From the Department of Medicine, University of Sydney, and the Commonwealth Scientific and Industrial \\ Research Organization, Glebe, Sydney, Australia
}

SUMMARY Long-chain fatty acid absorption in rats with a jejunal lesion similar to that which is found in adult coeliac disease has been studied. Neither changes in the solubility of the fatty acid in the intestinal lumen nor histological abnormalities of the villous epithelium accounted for the malabsorptive state. Evidence was obtained from studies in vivo of a disturbance in the intramucosal esterification of long-chain fatty acid. Assay of the activity of the microsomal enzymes responsible for the conversion of fatty acid to triglyceride revealed that this pathway was defective in the parasitized animals.

Rats which have been injected subcutaneously with larvae of the nematode Nippostrongylus brasiliensis develop a parasitic infestation of the proximal small intestine. The wall of the intestine is congested and dilated and mucosal inflammation is present (Taliaferro and Sarles, 1939). The villi are shortened and there is lengthening of the crypts (Symons and Fairbairn, 1962 and 1963). The similiarity between the mucosal lesion and that of coeliac disease has suggested that the infected rat may serve as a model for the study of the human disorder.

Previous studies in the infected animals have shown that the absorption of amino acids, monosaccharides, and electrolytes is depressed (Symons, 1960a and b). We have found that there is a marked impairment in the absorption of long-chain fatty acid which is accompanied by a disturbance of the mucosal enzymes concerned in triglyceride synthesis.

\section{Materials and Methods}

$\mathrm{C}^{14}$-carboxyl labelled palmitic, stearic and oleic acids (Radiochemical Centre, Amersham) were purified by thin-layer chromatography; the developing system contained by volume $58 \%$ hexane, $40 \%$ diethyl ether, and $2 \%$ glacial acetic acid. Sodium octanoate-1-C ${ }^{14}$ was converted to the free acid and purified in the same way. 1-Mono-olein (Distillation Products, Rochester, New York) by thin-layer chromatography contained less than $2 \%$ diglyceride or free fatty acid. Sodium taurocholate was synReceived for publication 12 July 1971. thesized by the method of Norman (1955) as modified by Playoust, Lack, and Weiner (1965).

Fatty acids were dissolved in small amounts of ether and were homogenized with a Potter-Elvehjem tissue grinder, either in a $10 \%$ solution of bovine albumin in Krebs-Ringer phosphate buffer (low calcium), or with mono-olein in a solution containing $24 \mathrm{mM}$ sodium taurocholate, $123 \mathrm{mM}$ $\mathrm{NaCl}, 4 \mathrm{mM} \mathrm{KCl}$, and $20 \mathrm{mM}$ sodium phosphate buffer, $p \mathrm{H} \mathrm{7 \cdot 1}$. The ether was evaporated at $40^{\circ} \mathrm{C}$ and the resultant clear or slightly opalescent solution was stable for the period of the experiment.

All experiments were carried out in fasted male Sprague Dawley rats weighing approximately $200 \mathrm{~g}$. Rats which were infected with Nippostrongylus brasiliensis received a subcutaneous injection of 6,000 larvae, either six or 10 days before the day of experiment.

EXPERIMENTS in vivo IN LIPID ABSORPTION Under ether anaesthesia, a $15-\mathrm{cm}$ segment of proximal jejunum was isolated and $1 \mathrm{ml}$ of a micellar solution containing $7 \cdot 2 \mu$ moles of stearic acid, $4 \cdot 8 \mu$ moles of 1 -mono-olein and $24 \mu$ moles of sodium taurocholate was injected into its lumen. The abdomen was closed and the animal was allowed to regain consciousness in a warmed cage. After 30 minutes the isolated segment of gut was removed intact and its contents were washed through with $40 \mathrm{ml}$ of ice-cold $1 \%$ albumin. Aliquots of homogenized lumenal contents were extracted by the method of Folch, Lees, and Stanley (1957). The 
chilled mucosa was expressed with a spatula onto a glass plate and homogenized in cold methanol. Its lipid component was extracted after the addition of chloroform. The mucosal lipids were fractionated by thin-layer chromatography. In experiments with octanoic acid, the analytical procedures were modified as described previously (Playoust and Isselbacher, 1964). Samples were assayed for total radioactivity by liquid scintillation spectroscopy of aliquots in toluene containing $0.3 \% 2,5$-diphenyloxazole and $0.01 \%$ bis-2 (5-phenyloxazolyl) benzene.

\section{EXPERIMENTS WITH JEJUNAL SLICES}

The animals were fasted overnight and killed by a blow on the head. Infected animals had received an injection of larvae 10 days previously. The proximal small intestine was everted over a rod and then divided into slices. Eight slices which were taken at random from paired rats were incubated in a medium containing $1 \cdot 8 \mu$ moles of (I-C $\left.{ }^{14}\right)$-oleic acid, $1 \cdot 1 \mu$ moles of 1 -mono-olein, and $24 \mu$ moles of sodium taurocholate in Krebs-Ringer bicarbonate solution, pH 7.4. Each flask was previously gassed for 20 minutes with a mixture of $95 \% \mathrm{O}_{2}$ and $5 \% \mathrm{CO}_{2}$. The slices were incubated in a Dubnoff shaking incubator for one hour at $25^{\circ} \mathrm{C}$ after which the reaction was stopped by placing the flasks in ice. The slices were removed and dried on filter paper, before measuring their wet weight. The dry weight of slices from control and infected rats was determined in separate experiments in which the previously incubated slices were heated to constant weight in an oven at $100^{\circ} \mathrm{C}$. The lipids of the homogenized slices were extracted and assayed for radioactivity as in the experiments in vivo.

\section{EXPERIMENTS WITH JEJUNAL MICROSOMES}

Fasted animals were killed by a blow on the head and the chilled jejunal mucosa was expressed onto a glass plate. One $\mathrm{g}$ of the mucosa was homogenized in $10 \mathrm{ml}$ of $0.278 \mathrm{M}$ mannitol in $0.01 \mathrm{M}$ trismaleate buffer, $p \mathbf{H} 7 \cdot 0$. The homogenate was filtered through washed gauze and centrifuged twice. The supernatant fluid was collected after discarding the pellets which were formed after centrifugation initially at $1,500 \mathrm{~g}$ for $15 \mathrm{~min}$ and then at $6,000 \mathrm{~g}$ for $20 \mathrm{~min}$. The microsomal pellet was obtained by centrifugation of the supernatant fluid at $105,000 \mathrm{~g}$ for $30 \mathrm{~min}$. The pellet was suspended in $2 \mathrm{ml}$ of $0.154 \mathrm{M}$ potassium chloride. Microsomal protein was measured by the method of Lowry, Rosebrough, Farr, and Randall (1951).

The ability of microsomal enzymes to esterify longchain fatty acid was measured in a system containing (I-C ${ }^{14}$ )-palmitic acid, $500 \mathrm{~m} \mu$ moles dissolved in $5 \%$ bovine albumin; DL- $\alpha$ glycerophosphate, $60 \mathrm{~m} \mu$
moles;ATP, $30 \mathrm{~m} \mu$ moles; glutathione, $20 \mathrm{~m} \mu$ moles; coenzyme A, $1 \mathrm{~m} \mu$ mole; magnesium chloride, 10 $\mathrm{m} \mu$ moles; potassium fluoride, $20 \mathrm{~m} \mu$ moles, in 0.5 $\mathrm{ml}$ of $0.5 \mathrm{M}$ trismaleate buffer, $p \mathrm{H} \mathrm{7.0.} \mathrm{Microsomal}$ protein $(1.2 \mathrm{mg})$ was added at the start of the incubation. After incubating for $30 \mathrm{~min}$ at $25^{\circ} \mathrm{C}$ the reaction was stopped by the addition of ice-cold, $2: 1$ chloroform methanol. After the completion of the lipid extraction the samples were fractionated by thin-layer chromatography and assayed for radioactivity as in the earlier experiments.

\section{Results}

EXPERIMENTS in vivo

Stearate absorption was markedly impaired in the nematode-infected rats (Table I). In experiments with jejunal segments which were prepared six and 10 days after infection absorption was $69 \%$ and $26 \%$ respectively of that which was found in control rats $(\mathrm{P}<0.0025)$. Washing the lumen with $40 \mathrm{ml}$ of

\begin{tabular}{lrl}
\hline & No. of Experiments & $\begin{array}{l}\text { Absorption } \\
\text { (mean } \pm S E \mu \text { moles })\end{array}$ \\
\hline Normal controls & 15 & $3 \cdot 9 \pm 0 \cdot 2$ \\
Six-day infection & 4 & $2 \cdot 7 \pm 0 \cdot 8$ \\
Ten-day infection & 6 & $1 \cdot 0 \pm 0 \cdot 2$ \\
\hline
\end{tabular}

Table I Absorption of a micellar solution containing $7 \cdot 2 \mu$ moles of $\left(I-C^{14}\right)$ stearic acid from isolated jejunal segments after 30 minutes

isotonic sodium chloride solution before administering the test solution did not alter the absorption of stearate. Chromatographic separation of the jejunal mucosal lipids from the infected rats revealed that there was an abnormal distribution of the radioactive label with an increased percentage in the free fatty acid fraction (Table II).

\begin{tabular}{|c|c|c|c|c|c|}
\hline & \multirow{2}{*}{$\begin{array}{l}\text { No. of } \\
\text { Experi- } \\
\text { ments }\end{array}$} & \multirow{2}{*}{$\begin{array}{l}\text { C'-activity in } \\
\text { Mucosal Lipids } \\
\text { (mean } \pm S E \\
\mu \text { moles) }\end{array}$} & \multicolumn{3}{|c|}{$\begin{array}{l}\text { Distribution of } C^{14} \text { - } \\
\text { activity }(\%)\end{array}$} \\
\hline & & & $T G F A$ & $D G M G$ & $P L$ \\
\hline $\begin{array}{l}\text { Normal controls } \\
\text { Ten-day infection }\end{array}$ & $\begin{array}{r}15 \\
\text { n }\end{array}$ & $\begin{array}{l}3.1 \pm 0.1 \\
0.8 \pm 0.3\end{array}$ & $\begin{array}{ll}72 & 14 \\
43 & 45\end{array}$ & $\begin{array}{l}4 \\
2\end{array}$ & \\
\hline
\end{tabular}

Table II Distribution of $C^{\mathbf{1 4}}$-activity in mucosal lipids of jejunal segments after instillation of $7 \cdot 2 \mu$ moles of stearic acid

In experiments in vivo with a medium-chain fatty acid each animal received $1 \mathrm{ml}$ of a solution containing $37 \mu$ moles of (I-C $\left.{ }^{14}\right)$-octanoate dissolved in $10 \%$ albumin. No difference was noted in the ab- 
sorption of octanoate by the control and infected rats. $32.4 \pm 0.2 \mu$ moles (mean \pm standard error) was absorbed from the jejunal segments in five control experiments and $29.7 \pm 1.0 \mu$ mole in the same number of experiments in infected animals.

\section{EXPERIMENTS WITH JEJUNAL SLICES}

The incorporation of (I-C $\left.{ }^{14}\right)$-oleic acid into its esters was reduced in jejunal slices from the infested rats (Table III). Inclusion of the intestinal contents from the infected animals did not affect the esterification of the fatty acid by control slices.

\begin{tabular}{lll}
\hline & $\begin{array}{l}\text { Fatty Acid ( } \mu \text { moles) } \\
\text { per } \mathrm{g} \text { Wet Tissue }\end{array}$ & $\begin{array}{l}\text { Fatty Acid ( } \mu \text { moles) } \\
\text { per } \mathrm{g} \text { Dry Tissue }\end{array}$ \\
\hline $\begin{array}{l}\text { Control slices } \\
\text { Control slices plus }\end{array}$ & $2 \cdot 8$ & 19.0 \\
infected jejunal & & \\
contents & $2 \cdot 3$ & 16.0 \\
Infected slices & $1 \cdot 1$ & 7.0 \\
\hline
\end{tabular}

Table III Esterification of $\left(I-C^{14}\right)$-oleic acid by slices of rat jejunum

EXPERIMENTS WITH JEJUNAL MICROSOMES The ability of the enzymes in a microsomal preparation of jejunal mucosa to convert (I-C $\left.\mathrm{C}^{14}\right)$-palmitic acid into its fatty acid esters was reduced in the infected rats (Table IV). The presence of microsomes from the jejunal mucosa of infected rats failed to reduce the esterification of palmitic acid by microsomes from control animals.

\begin{tabular}{ll}
\hline & $\begin{array}{l}\text { Labelled Fatty Acid Esterified }(\mathrm{m \mu} \text { moles } / \mathrm{mg} \\
\text { protein/hr) }\end{array}$ \\
\hline $\begin{array}{ll}\text { Control microsomes } \\
\text { Infected microsomes }\end{array}$ & 498 \\
Control and Infected & 76 \\
microsomes & 574 \\
\hline
\end{tabular}

Table IV Esterification of $\left(\mathrm{I}-\mathrm{C}^{14}\right)$-palmitate by rat jejunal microsomes ${ }^{1}$

${ }^{2}$ Details of the assay system are provided in the text.

\section{Discussion}

The malabsorption in the infected animals could have resulted from physicochemical changes affecting the solubility of the fatty acid in the intestinal lumen or from changes in the absorptive epithelium. The defect in absorption remained when the segments were washed thoroughly with isotonic sodium chloride solution before the instillation of the dose. Thus binding of the fatty acid to cellular debris or to the parasites was not responsible for the disturbance in absorption. Defective micellar solubilization by bile salts would also interfere with the absorption of fatty acid but under the conditions of the experiments sodium taurocholate was present in high concentration. The possibility that a reduction in the absorptive surface was a factor in producing fatty acid malabsorption must also be considered. However, despite the changes in individual villi the increase in the diameter of the jejunum has been shown to compensate for any loss of surface area (Symons and Fairbairn, 1962).

A more likely explanation of the malabsorption of fatty acid is that it was secondary to a biochemical lesion in the jejunal epithelial cells. An increase in the unesterified fatty acid fraction of the mucosal lipids was found in the experiments in vivo and in vitro. The incorporation of fatty acid into its esters was markedly reduced in the experiments with jejunal slices. These experiments suggested that the intramucosal lesion was not due to the effect of a toxin for inclusion of the jejunal contents from infected rats in the incubation medium did not affect fatty acid esterification by control slices. Additional evidence for a defect in esterification was obtained in the experiments with octanoate, a medium-chain fatty acid which, unlike long-chain fatty acids, undergoes minimal esterification during its passage through the intestinal epithelium (Playoust and Isselbacher, 1964). The finding that octanoate absorption was not depressed in the infected rats may then be regarded as evidence that the malabsorption of long-chain fatty acid was linked with faulty mucosal esterification.

The assay system which was used to measure the activity of the microsomal enzymes provides a measure of the efficiency of the phosphatidic acid pathway, one of two pathways by which intestinal triglyceride synthesis occurs (Senior, 1964). Fatty acid enters this pathway after preliminary activation, catalysed by a fatty acid-CoA ligase or thiokinase. Two moles of acyl-CoA combine with one mole of DL- $\alpha$ glycerophosphate to form phosphatidic acid, which is a diglyceride precursor. Triglycerides are then formed from diglycerides by the addition of a further mole of acyl-CoA. Esterification of palmitic acid by this pathway was severely depressed in the infected rats. We have not attempted to identify the enzyme or enzymes which are concerned, nor have we tested the possibility that defective incorporation of triglycerides into chylomicrons also occurs. It is of interest, in view of the similarity in the mucosal lesion, that a reduction in fatty acid-CoA ligase activity has been found in the jejunal mucosa of patients with coeliac disease (Dawson and Isselbacher, 1960). 
The present findings of deficient microsomal fatty acid esterifying enzymes, as well as previous studies demonstrating a reduction in brush border and mitochondrial enzymes (Symons and Fairbairn, 1962) may reflect mucosal trauma due to the presence of the parasites. However, there is now evidence that there is an increase both in the rate of cell loss from the villous tips and in the rate of migration of crypt cells onto the villus in rats with Nippostrongylus brasiliensis (Symons, 1965; Loehry, Croft, Singh, and Creamer, 1969; Loehry and Creamer, 1969). Thus the defective enzyme complement may be a reflection of a relative increase in the number of incompletely differentiated epithelial cells in the intestinal villus. On this basis, the malabsorption of fatty acid, and possibly of other nutrients, could be secondary to a defect in the maturation of the intestinal epithelium. A similar conclusion based on electronmicroscopic and histochemical analyses of jejunal epithelium was reached in a study of nontropical sprue (Padykula, Strauss, Ladman, and Gardner, 1967).

This work was supported by the Wellcome Trust, the Bushell Trust, and the Post Graduate Medical Foundation of the University of Sydney. We thank Mr D. E. Pacey and Miss Pamela Rothman for their help.

\section{References}

Dawson, A. M., and Isselbacher, K. J. (1960). The esterification of palmitate-I-C14 by homogenates of intestinal mucosa. J. clin. Invest., 39, 150-160.

Folch, J., Lees, M., and Stanley, G. H. S. (1957). A simple method for the isolation and purification of total lipides from animal tissues. J. biol. Chem., 226, 497-509.

Loehry, C. A., and Creamer, B. (1969). Three-dimensional structure of the rat small intestinal mucosa related to mucosal dynamics. III. Mucosal structure and dynamics in the rat infested with the nematode, Nippostrongylus brasiliensis. Gut, 10, 119-120.

Loehry, C. A., Croft, D. N., Singh, A. K., and Creamer, B. (1969). Cell turnover in the rat small intestinal mucosa: An appraisal of cell loss. II. Cell loss in rats with an abnormal mucosa. Gut, 10, 16-18.

Lowry, O. H., Røsebrough, N. J., Farr, A. L., and Randall, R. J. (1951). Protein measurement with the folin phenol reagent. $J$. biol. Chem., 193, 265-276.

Norman, A. (1955). Preparation of conjugated bile salts using mixed carboxylic acid anhydrides. Arkiv Kemi., 8, 331-342.

Padykula, H. A., Strauss, E. W., Ladman, A. J., and Gardner, F. H. (1961). A morphologic and histochemical analysis of the human jejunal epithelium in nontropical sprue. Gastroenterology, 40, 735-765.

Playoust, M. R., and Isselbacher, K. J. (1964). Studies on the intestinal absorption and intramucosal lipolysis of a medium chain triglyceride. J. clin. Invest., 43, 878-885.

Playoust, M. R., Lack, L., and Weiner, I. M. (1965). Effect of intestinal resection on bile salt absorption in dogs. Amer. $J$. Physiol., 208, 363-369.

Senior, J. R. (1964). Intestinal absorption of fats. J. Lipid Res., 5, 495-521.

Symons, L. E. A. (1960a). Pathology of infestation of the rat with Nippostrongylus muris (Yokogama) IV. The absorption of glucose and histidine. Aust. J. biol. Sci., 13, 180-187.

Symons, L. E. A. (1960b). Pathology of infestation of the rat with Nippostrongylus muris (Yokogama) III. Jejunal flux as in vivo of water sodium and chloride. Aust. J. biol. Sci., 13, 171-179.

Symons L. E. A. (1965). Kinetics of the epithelial cells, and morphology of villi and crypts in the jejunum of the rat infected by the nematode. Nippostrongylus brasiliensis. Gastroenterology, 49, 158-168.

Symons, L. E. A., and Fairbairn D. (1962). Pathology, absorption, transport, and activity of digestive enzymes in rat jejunum parasitized by the nematode, Nippostrongylus brasiliensis. Fed. Proc., 21, 913-918.

Symons, L. E. A., and Fairbairn, D. (1963). Biochemical pathology of the rat jejunum parasitized by the nematode, Nippostrongylus brasiliensis. Exp. Parasit., 13, 284-304.

Taliaferro, W. H., and Sarles, M. P. (1939). The cellular reactions in the skin, lungs and intestine of normal and immune rats after infection with Nippostrongylus muris. J. infect. Dis., 64, 157-192. 